\title{
Efficacy of Plant Extracts on the Germination of Wheat Seeds
}

\author{
Rajendra Kumar Seth, Shah Alam, and D.N. Shukala \\ Bhargava Agricultural Botany laboratory, Department of Botany, University of Allahabad, Allahabad 211002
}

\begin{abstract}
Seeds of wheat were treated with eight locally available indigenous plants namely. Allium sativum (Garlic), Datura stramonium (Datura), Azadirachta indica (Neem), Allium cepa var. aggregatum (Onion), Carica papaya (Papaya), Zingiber officinal (Ginger), Parthenium hysterophorvus (Parthenium), and Curcuma longa (Turmeric) were evaluated. I have been collected from farmer's storages of Varanasi U.P. India. The first aim was to characterize the antifungal activities of leaf extract with acetone, methanol and water as solvents on the most frequently occurring wheat pathogens of the loose smut (Ustilago tritici) in Varanasi. Among the treated wheat seeds, the highest germination was found in 95.58 Seeds were treated with solvents 'Water' plant extracts at 5.0, 7.5, and 10\% of solutions in respective plant extracts, 93.95 Seeds were treated with solvents 'Methanol' at 5.0, 7.5, and 10\% of solutions in respective plant extracts than 92.20 Seeds were treated with solvents 'Acetone' at 5.0, 7.5, and 10\% of solutions in respective plant extracts. Growth promoting activities of leaf extract on wheat seedling vigour was reported. Interestingly, the inoculums on naturally infected wheat seeds could be reduced with plant extract as a seed dressing biofungicide, before sowing. In this study we demonstrated the efficacy and the high control potential of leaf extract against seed-borne wheat fungi.
\end{abstract}

Key word: Seed Germination, Seed treatment, Seed borne fungi, Wheat

\section{Introduction}

Wheat (Triticum aestivum L.) is one of the first domesticated food crops and for 8,000 years has been the basic staple food in major part of Europe. West Asia and North Africa (CIMMYT, 2009). Wheat is one of the most important cereals for human diet and easily digested by nearly $99 \%$ of human population all over the world. It is one of the important cereal crops and major food grains in India. A considerable amount of wheat as well as other grains is lost every year in storage due to biotic and abiotic factors. Stored wheat grains are subjected to the attack of many pests and diseases in storage. There are approximately 200 species of insects and mites attacking stored grains and stored products (Maniruzzaman, 1981). Gentile and Trematerra (2004) reported that 20 insect pests infested stored wheat, while Chaudhury and Mahla observed 10 insect species of wheat in storage. Their attacks reduced both quantity and food value of stored seeds. In India, most of the farmers are poor and marginal and store small quantities of wheat grains in their houses for consumption and seed purpose.

Agricultural crops are exposed to approximately 70,000 species of pests, but of these only $10 \%$ are considered serious pests (Pimentel, 1997). After harvest, another 20\% of the food is lost to another group of pests (Pimentel, 1997). Plant diseases caused by a variety of fungi may cause significant losses on agricultural crops. All plants are attacked by some kinds of fungi, and each of parasitic fungi can attack one or many kinds of plants. More than 10,000 species of fungi can cause disease in plants (Agrios, 2005).

Fungal diseases may be minimized by the reduction of the inoculums, inhibition of its virulence mechanisms and promotion of genetic diversity in the crop (Strange and Scott, 2005). Fungicides may also prevent the growth of fungi that produce toxins, such as aflatoxins. In 1997, worldwide, 5.7 billion pounds of pesticides were used, of which 0.5 billion were fungicides (Goldman, 2008). There are numerous classes of fungicides, with different modes of action as well as different potential for adverse effect on health and environment. Milne (2004) indicated 311 compounds are registered and used as fungicides to control various plant fungal diseases. Of these, seven agents are antagonistic microorganisms and only one agent is derived from plant extract, i.e., extract of Reynoutria sachalinensis (Giant Knotweed).

Different kinds of preventive and curative control measures are practiced to protect these pests. Among those, chemical pesticides have been used for a long time, but have serious drawbacks (Sharaby, 1988), such as direct toxicity to beneficial insects, fishes, and human (Pimental, I981), pesticides resistance (Brown, 1968), health hazard (Bhaduri et al., 1989) and increased environmental and social costs (Pimental et al., 1980). In many countries, efforts are being made to minimize the use of harmful insecticides through the use of indigenous plant products, implementation of IPM approaches, use of bio-degradable products (Khattach and Hameed, 1986) and applying insect growth regulators (Metcalf, 1975) to protect stored grains. In many areas of the world, locally available plant materials are widely used to protect stored product against damage by insect infestation (Golob and Webley, 1980). 
The identified seed borne fungi diseases of Wheat were antifungal activity against plant pathogenic fungi such as loose smut (Ustilago tritici) was determined in vivo by observing the inhibition of plant disease development. Seeds of Wheat were treated with 8 locally available indigenous plants namely. Allium sativum (Garlic), Datura stramonium (Datura), Azadirachta indica (Neem), Allium cepa var. aggregatum (Onion), Carica papaya (Papaya), Zingiber officinal (Ginger), Parthenium hysterophorvus (Parthenium), and Curcuma longa (Turmeric) may be grown by farmers with minimum cost and extracted by indigenous methods. And I have been investigated for their compatibility in the IPM programmed by determining their toxic (Mamun et al., 2009), repellent (Mamun et al., 2008), residual and grain protectant (Mamun et al., 2008b). So, it is important to know the effect of such indigenous plant extracts on the germination of wheat seeds but a few studies have been done on this. Therefore, the present study was undertaken to determine the effect of these botanicals on the germination of Wheat seed.

\section{Plant Material}

\section{Materials and Methods}

The present study was conducted in the Bhargawa Agricultural botany laboratory, of the Department of Botany, University of Allahabad, Allahabad, during the period from October 2013 to March 2014. Wheat seeds of the variety 'Sonalika' were collected from District Varanasi (U.P.) India.

\section{Preparation of plant extracts}

The various parts were collected to fresh leaves of Garlic, Datura, Neem, Onion, Papaya, Ginger, Parthenium, and Turmeric grass were collected from the surroundings of District Varanasi (U.P.). Afterwards, they were washed in running water. The plants were kept in shade for air-drying and then they were dried in the oven at $45^{\circ} \mathrm{C}$ to gain constant weight. Dusts were prepared by pulverizing the dried leaves with the help of a grinder. Then the dusts were passed through a 25 -mesh diameter sieve to obtain fine and uniform dint. The dusts were preserved in airtight condition in polythene bags till their use in extract preparation. The powder from all the samples was carefully stored a $-20{ }^{\circ} \mathrm{C}$. Water-soluble extracts were prepared as described by RivillasAcevedo and Soriano-García (2007), with some modifications.

The prepared leaf dusts were used for preparation of plant extracts. Each category dust $(15 \mathrm{gm})$ was taken in a $500 \mathrm{ml}$ beaker and mixed separately with $100 \mathrm{ml}$ of different solvents (acetone, methanol, and distilled water). Then the mixture was stirred for 30 minutes by a magnetic stirrer at (5000 rpm) and left to stand for next 24 hours. The mixture was then filtered through a fine cloth and again through filter paper (Whatman No. I). The filtrated materials were taken in a round bottom flask and condensed by evaporation of solvent in a water bath at $40^{\circ} \mathrm{C}, 50^{\circ} \mathrm{C}$, and $60^{\circ} \mathrm{C}$ temperature for acetone, methanol, and water extracts, respectively. Evaporation was done to make the volume $10 \mathrm{ml}$. After the evaporation of solvent, the condensed extracts were preserved in tightly corked labeled bottles and stored in a refrigerator until their use. Different concentrations of plant extracts were prepared by dissolving the stock solutions in the respective solvent prior to germination test of wheat seeds. The resulting aqueous solution was used for the fungal growth inhibition assay.

The germination of the treated wheat seed was evaluated by the process described by Qi and Burkholder (1981). The seeds were treated with different plant extracts at 5.0, 7.5, and 10.0\% of respective plant extracts. The treated seeds were then dried under shade and kept for 3 months in the plastic container to prevent infestation. The seeds were then taken to test their germination by using blotting paper method (Agrawal, 1980). 100 seeds from each treatment were placed on petridishe of $9.0 \mathrm{~cm}$ diameter containing water soaked blotting paper. Each treatment was replicated thrice. The well germinated seeds in each petridish were counted after 7 days of treatment and expressed in number of seed germination.

Table: 1 List of plants used for antifungal properties

\begin{tabular}{|c|c|c|c|c|}
\hline SI. No. & Common Name & Family & Botanical Name & Part used \\
\hline 1 & Garlic & Amaryllidaceae & Allium sativum & Leaf \\
\hline 2 & Datura & Solanaceae & Datura stramonium & Leaf \\
\hline 3 & Neem & Meliaceae & Allium cepa var. aggregatum & Leaf \\
\hline 4 & Onion & Amaryllidaceae & Carica papaya & Leaf \\
\hline 5 & Papaya & Caricaceae & Zingiber officinal & Leaf \\
\hline 6 & Ginger & Zingiberaceae & Parthenium hysterophorvus & Leaf \\
\hline 7 & Parthenium & Asteraceae & Curcuma longa & Leaf \\
\hline 8 & Turmeric & Zingiberaceae & &
\end{tabular}


Table: 2 Different concentrations of plant extracts were prepared by dissolving the stock solutions in the respective solvent prior to germination test of wheat seeds.

\begin{tabular}{|c|c|c|c|c|c|c|}
\hline \multirow{2}{*}{$\begin{array}{c}\text { Leaf Extract of Plant } \\
\text { Allium sativum } \\
\end{array}$} & \multicolumn{2}{|c|}{$\begin{array}{c}\text { Leaf extract }+ \text { Water in } \\
\text { (Dilute) }\end{array}$} & \multicolumn{2}{|c|}{$\begin{array}{c}\text { Leaf extract }+ \text { Acetone in } \\
\text { (Dilute) }\end{array}$} & \multicolumn{2}{|c|}{$\begin{array}{c}\text { Leaf extract + Methanol in } \\
\text { (Dilute) }\end{array}$} \\
\hline & $15 \mathrm{gm}$ & $100 \mathrm{ml}$ & $15 \mathrm{gm}$ & $100 \mathrm{ml}$ & $15 \mathrm{gm}$ & $100 \mathrm{ml}$ \\
\hline Datura stramonium & $15 \mathrm{gm}$ & $100 \mathrm{ml}$ & $15 \mathrm{gm}$ & $100 \mathrm{ml}$ & $15 \mathrm{gm}$ & $100 \mathrm{ml}$ \\
\hline Azadirachta indica & $15 \mathrm{gm}$ & $100 \mathrm{ml}$ & $15 \mathrm{gm}$ & $100 \mathrm{ml}$ & $15 \mathrm{gm}$ & $100 \mathrm{ml}$ \\
\hline $\begin{array}{c}\text { Allium cepa var. } \\
\text { aggregatum }\end{array}$ & $15 \mathrm{gm}$ & $100 \mathrm{ml}$ & $15 \mathrm{gm}$ & $100 \mathrm{ml}$ & $15 \mathrm{gm}$ & $100 \mathrm{ml}$ \\
\hline Carica papaya & $15 \mathrm{gm}$ & $100 \mathrm{ml}$ & $15 \mathrm{gm}$ & $100 \mathrm{ml}$ & $15 \mathrm{gm}$ & $100 \mathrm{ml}$ \\
\hline Zingiber officinal & $15 \mathrm{gm}$ & $100 \mathrm{ml}$ & $15 \mathrm{gm}$ & $100 \mathrm{ml}$ & $15 \mathrm{gm}$ & $100 \mathrm{ml}$ \\
\hline Parthenium hysterophorvus & $15 \mathrm{gm}$ & $100 \mathrm{ml}$ & $15 \mathrm{gm}$ & $100 \mathrm{ml}$ & $15 \mathrm{gm}$ & $100 \mathrm{ml}$ \\
\hline Curcuma longa & $15 \mathrm{gm}$ & $100 \mathrm{ml}$ & $15 \mathrm{gm}$ & $100 \mathrm{ml}$ & $15 \mathrm{gm}$ & $100 \mathrm{ml}$ \\
\hline
\end{tabular}

\section{Results and discussion}

The present study tested the antifungal activity of leaf extracts and their respective dilutions from plants extract belonging to eight plant families against Ustilago tritici. These plants extract were chosen based on either traditional usage (Table:1), suggestive of antimicrobial activity, or previous studies that have demonstrated antifungal properties using different kinds of extracts (Guo et al., 1997; Wilson et al., 1997; Zhu et al., 2005).

Table: 3 the seeds were treated with solvents 'Water' plant extracts at 5.0, 7.5, and $10 \%$ of solutions in respective plant extracts.

\begin{tabular}{|c|c|c|c|c|}
\hline Leaf Extract of Plant & $5.0 \%$ (Water) & $7.5 \%$ (Water) & $10.0 \%$ (Water) & Average \\
\hline Allium sativum & 95 & 97 & 98 & 96.66 \\
\hline Datura stramonium & 94 & 96 & 97 & 95.66 \\
\hline Azadirachta indica & 95 & 98 & 96 & 96.33 \\
\hline Allium cepa var. aggregatum & 97 & 96 & 99 & 97.33 \\
\hline Carica papaya & 93 & 95 & 98 & 95.33 \\
\hline Zingiber officinal & 92 & 94 & 96 & 94.00 \\
\hline Parthenium hysterophorvus & 96 & 93 & 94 & 94.33 \\
\hline Curcuma longa & 94 & 96 & 95 & 95.00 \\
\hline \multicolumn{3}{|c|}{ Note - Number of seeds germination rate in table: 3} & \multicolumn{2}{|c|}{$\begin{array}{c}\text { Total Average } \\
764.64 / 8=95.58 \text { Seeds. }\end{array}$} \\
\hline
\end{tabular}

I have taken 100 seeds, the study were tested the antifungal activity of plant extracts and their effect of respective dilutions from plant extract with different plant extracts at 5.0, 7.5, and 10\% of solutions in respective leaf extracts. I found different resulted.

Table: 4 the seeds were treated with solvents 'Acetone' at 5.0, 7.5, and $10 \%$ of solutions in respective plant extracts.

\begin{tabular}{|c|c|c|c|c|}
\hline Leaf Extract of Plant & $\mathbf{5 . 0} \%$ (Acetone) & $\mathbf{7 . 5 \%}$ (Acetone) & $\mathbf{1 0 . 0} \%$ (Acetone) & Average \\
\hline Allium sativum & 92 & 94 & 93 & 93.00 \\
\hline Datura stramonium & 94 & 93 & 95 & 94.00 \\
\hline Azadirachta indica & 91 & 94 & 92 & 92.33 \\
\hline Allium cepa var. aggregatum & 93 & 95 & 94 & 94.00 \\
\hline Carica papaya & 93 & 92 & 94 & 93.00 \\
\hline Zingiber officinal & 90 & 87 & 88 & 88.33 \\
\hline Parthenium hysterophorvus & 92 & 93 & 94 & 93.00 \\
\hline Curcuma longa & 89 & 90 & 91 & 90.00 \\
\hline
\end{tabular}

Table: 5 the seeds were treated with solvents 'Methanol' at 5.0, 7.5, and $10 \%$ of solutions in respective plant extracts.

\begin{tabular}{|c|c|c|c|c|}
\hline Leaf Extract of Plant & $5.0 \%$ (Methanol) & $7.5 \%$ (Methanol) & $10.0 \%$ (Methanol) & Average \\
\hline Allium sativum & 93 & 95 & 94 & 94.00 \\
\hline Datura stramonium & 95 & 94 & 96 & 95.00 \\
\hline Azadirachta indica & 93 & 95 & 94 & 94.00 \\
\hline Allium cepa var. aggregatum & 94 & 94 & 94 & 94.00 \\
\hline Carica papaya & 93 & 94 & 95 & 94.00 \\
\hline Zingiber officinal & 95 & 93 & 92 & 93.33 \\
\hline Parthenium hysterophorvus & 95 & 94 & 96 & 95.00 \\
\hline Curcuma longa & 92 & 93 & 92 & 92.33 \\
\hline \multicolumn{3}{|c|}{ Note - Number of seeds germination rate in table:5 } & \multicolumn{2}{|c|}{$\begin{array}{c}\text { Total Average } \\
751.66 / 8=93.95 \text { Seeds. }\end{array}$} \\
\hline
\end{tabular}


Table: 6 Germination rate of wheat seeds treated with different plant extracts of different solvents.

\begin{tabular}{|c|c|c|c|c|}
\hline Plant extract & $\begin{array}{c}\text { Water } \\
\text { solvents }\end{array}$ & $\begin{array}{l}\text { Acetone } \\
\text { solvents }\end{array}$ & $\begin{array}{c}\text { Methanol } \\
\text { solvents }\end{array}$ & $\begin{array}{c}\text { Average } \\
\text { value }\end{array}$ \\
\hline Allium sativum & 96.66 & 93.00 & 94.00 & 94.55 \\
\hline Datura stramonium & 95.66 & 94.00 & 95.00 & 94.88 \\
\hline Allium cepa var. aggregatum & 97.33 & 94.00 & 94.00 & 95.11 \\
\hline Carica papaya & 95.33 & 93.00 & 94.00 & 94.11 \\
\hline Zingiber officinal & 94.00 & 88.33 & 93.33 & 91.88 \\
\hline Curcuma longa & 95.00 & 90.00 & 92.33 & 92.44 \\
\hline
\end{tabular}

Note - Number of seeds germination rate of average value with different plant extracts and different solvents in table 6.

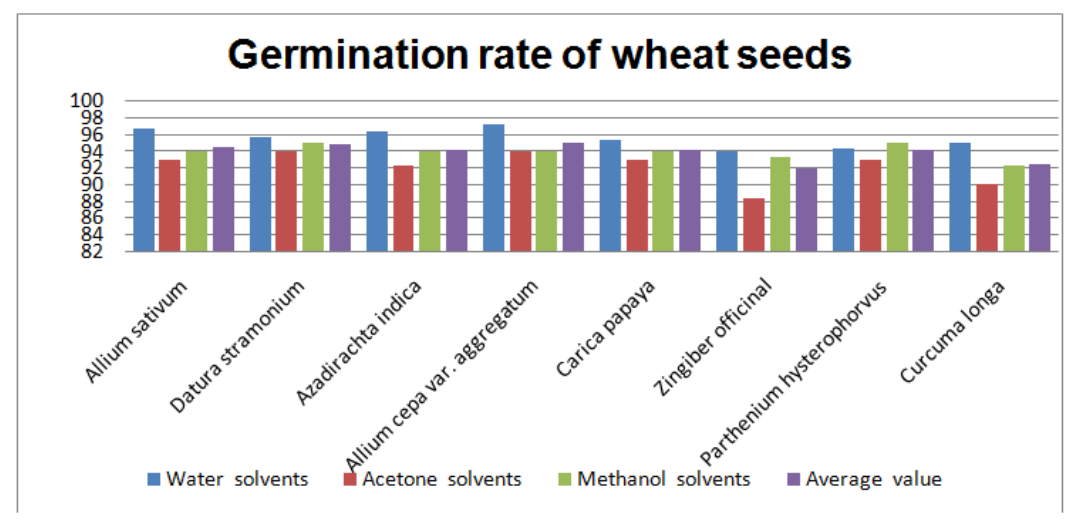

Results on the effect of different plant and plant part extracts had significant effect on germination of wheat seeds in Table 3-5. Interaction of different plant parts at different dose level had significant effect on germination of wheat seeds and the highest germination seeds were recorded in leaf extracts. Among the solvents, the highest germination 95.58 per seeds (table 3) was found in wheat seeds treated with water extracts followed by methanol 93.95 per seeds (table 4) and acetone 92.20 per seeds (table 5) extracts. Number of seeds germination rate of average value with different plant extracts of different solvents in table 6 . The interaction effects of different doses and different plant extracts showed that the average germination was the highest and the lowest dose level. Germination of wheat seeds decreases gradually with the increase of doses (Table 3-5).

Among the treated wheat seeds, the highest germination was found in Allium cepa var. aggregatum (Onion) treated wheat seeds and the lowest in Zingiber officinal (Ginger) treated wheat seeds. Number of seeds germination was always higher in wheat seed treated with leaf extract. There are solvent methanol extracts, the highest germination was observed in Parthenium hysterophorvus (Parthenium), and Datura stramonium (Datura) and the lowest in Curcuma longa (Turmeric). And number of seeds germination was higher in Allium cepa var. aggregatum (Onion) and Datura stramonium (Datura), the lowest germination was observed in Zingiber officinal (Ginger) to wheat seeds treated from acetone extract. Germination of wheat seeds decreased gradually with increase of doses. All the tested plants did not show any adverse effect on germination of seeds up to 8 days of treatments. The present findings are almost in agreement with those of Islam (2001); Khaire et al (1992), Gupta et al. (1988), where they reported that seeds treated with plant materials did not adversely affect the seed germination. Farmers may use these plant extracts in their storage structure for management of stored grain pests without any adverse effect on germination of treated seeds.

\section{Conclusions}

The study has shown that 12 locally available indigenous plants namely. Allium sativum (Garlic), Datura stramonium (Datura), Azadirachta indica (Neem), Allium cepa var. aggregatum (Onion), Carica papaya (Papaya), Zingiber officinal (Ginger), Parthenium hysterophorvus (Parthenium), and Curcuma longa (Turmeric) are very effective in inhibiting the fungal growth of Ustilago tritici. Therefore, it may be concluded that plant extract can successfully be used for controlling seed borne fungal pathogens of wheat instead environment hazardous chemicals for treating seeds of wheat in India. 


\section{Acknowledgements}

We are thankful to my sincerely Supervisor Prof. D.N. Shukla Department of Botany, University of Allahabad, Allahabad, India for Providing Laboratory Facilities and I also thanks to my friend Shah Alam for views and opinions expressed in this article.

\section{Reference}

[1]. Agrios, G.N., 2005. Plant Pathology. 5 Editions. Academic Press, San Diego, USA.

[2]. Agrawal, R.L. 1980. Seed germination. pp. 515-518. In: Seed Technology (2nd edn.). Oxford \& IBH Pub. Co. Pvt. Ltd., New Delhi, India. $829 \mathrm{p}$.

[3]. Bhaduri, N., D.P. Gupta and S. Ram. 1989. Effect of vegetable oils on the ovipositional behaviour of Callosobruchus chinensis Fab. pp. 81-84. In: Proc. 2nd Int. Symp. On Bruchids and Legumes (ISBL-2), Okayama, Japan.

[4]. Chaudhury, S.D. and J.C. Mahla. 2001. Insect pests infesting stored wheat in different climatic region of Haryana. Crops Res. Hisar 2(3): 384-386.

[5]. CIMMYT. 2009. Wheat facts and future 2009. In: Dixon, J., H. Joachim, B. P. Kosina and C. Jonathan (Eds.). International Maize and Wheat Improvement Centre. Mexico. 1-95p

[6]. Guo, B.Z., Z.Y. Chen, R.L. Brown, A.R. Lax, T.E. Cleveland, J.S. Russin, et al. 1997. Germination induces accumulation of specific proteins and antifungal activities in corn kernels. Phytopathology 87:1174-1178.

[7]. Golob, P. and D.J. Webley. 1980. The use of plants and minerals as traditional protectants of stored products. Rep. Trop. Prod. Inst $32 \mathrm{p}$.

[8]. Gentile. P. and P. Trematerra. 2004. Insect pests of hulled wheat and ecology of Sitotroga cerealella.(Olivier). Technica Motitoria 55(9): 855-862.

[9]. Gupta. H.C., J.P. Verma, S.S. Bareth and B.N. Mathur. 1988. Evaluation of some nonedible oils as grain protectant in wheat and their subsequent effect on germination. Indian J. Entomol. 50(2): 147-150.

[10]. Islam, M.S. 2001. Laboratory evaluation of some indigenous plant extracts against granary weevil, Sitophilus granarus L. (Coleoptera: Curculionidae). M.S. Thesis, Dept. Entomology, Bangladesh Agril. Univ., Mymensingh. 135 P.

[11]. Khaire, V.M., B.V. Kachare and U.N. Mote. 1992. Efficacy of different vegetable oils as grain protectants against Pulse beetle, Callosobruchus chinensis L. in increasing storability of pigeon pea. J. Stored Prod. Res. 28(3): 153-156.

[12]. Khattach, S.U. and M. Hameed. 1986. Control of pulse beetle, callosobruchus chinensis L. by gamma radiation, irradiated as unmated adults. Bangladesh J. Zool. 14(2): 167-169

[13]. Metcalf, R.L. 1975. Insecticides in pest management. pp. 235-273. In: R.L. Metcalf and W. Luckmann (Eds.). Introduction to Insect Pest Management. Wiley-Inter. Sci. New York.

[14]. Mamun, M. S. A., M. Shahjahan and M. Ahmad. 2008a. Laboratory evaluation of some indigenous plant extracts as repellent against red flour beetle, Tribolium castaneum Herbst. Bangladesh J. Entomol. 18(1): 91-99.

[15]. Mamun, M.S.A., M. Shahjahan and M. Ahmad. 2008b. Residual and grain protection effect of some indigenous plant extracts against red flour beetle, Tribolium castaneum Herbst. Bangladesh J. Seed Sci. \& Tech. 12(2): 141-145.

[16]. Mamun, M.S.A. M. Shahjahan and M. Ahmad. 2009. Laboratory evaluation of some indigenous plant extracts as toxicant against red flour beetle, Tribolium castaneum Herbst. J. Bangladesh Agril. Univ. 7(1): 1-5

[17]. Maniruzzaman, F.M. 1981. Plant Protection in Bangladesh. National Book Centre. 67/-A, Purana Paltan, 325p.

[18]. Pimental, D. 1981. An overview of integrated pest management (Mimeograph). Department of Entomology, Section of Ecology and Systematic, Cornell University, Ithaca, N.Y. p. 522.

[19]. Pimental, D., D. Andow, D. Dyson-Hudson. D. Gallahan, S. Jacobson, M. Irish, S. Croop, A. Moss, I. Schreiner, M. Shepard, T. Thompson and B. Vinzant. 1980. Environmental and social cost of pesticides. A preliminary assessment. Oikos 34: $125-140$

[20]. Qi, W.T. and W.E. Burkholder. 1981. Protection of stored wheat from the granary weevil by vegetable oils. J. Econ. Entomol. 74: 502-505.

[21]. Rivillas-Acevedo, L.A., and M. Soriano-García. 2007. Isolation and biochemical characterization of an antifungal peptide from Amaranthus hypochondriacus seeds. Journal of Agricultural and Food Chemistry 55:10156-10161.

[22]. Strange RN, Scott PR (2005) Plant disease: a threat to global food security. Annual Review of Phytopathology, 43, 83-116.

[23]. Sharaby, A. 1988. Evaluation of some Mytraceae plant leaves as protectants against the infestation by Sitophilus oryzae L. and Sitophilus granarius L. Insect Sci. Appl. 9: 465-468.

[24]. Wilson, C.L., J.M. Solar, A. El Ghaouth, and M.E. Wisniewski. 1997. Rapid evaluation of plant extracts and essential oils for antifungal activity against Botrytis cinerea. Plant Disease 81:204-210.

[25]. Zhu, X.F., H.X. Zhang, and R. Lo. 2005. Antifungal activity of Cynara scolymus L. extracts. Fitoterapia 76:108-111. 